\title{
Assessing of Oil Refinery Plant Residues on Soil Contamination in Kasnazan District - Erbil, Iraqi Kurdistan Region
}

\author{
Ismaeel T. Ahmed*, Darseem B. Ismael \\ Department of Soil and Water, College of Agriculture Engineering Sciences, Salahaddin University, Erbil, Kurdistan Region - Iraq
}

\author{
*Corresponding author: \\ Ismaeel T. Ahmed, \\ Department of Soil and \\ Water, College of Agriculture \\ Engineering Sciences, \\ Salahaddin University, Erbil, \\ Kurdistan Region - Iraq. \\ E-mail: ismaeel.ahmed@ \\ su.edu.krd
}

\begin{tabular}{l} 
Received: 12 January 2019 \\
Accepted: 26 March 2019 \\
Published: 01 December \\
2019 \\
\hline DOI \\
10.25156/pj.v9n2y2019.pp112-118
\end{tabular}

\section{A B S T R A C T}

This investigation conducted on April 01, 2015, of the different locations surrounding oil refinery factories near the Kasnazan district on Sulaimani road (Latitude 36.211N, Longitude 44.157E), to assess the effects of oil refinery factory residues on soil contamination. Soil samples were collected towards ( $E$ and $W$ ) from the contamination source, with various distances $(0.5,1$, and $1.5 \mathrm{~m})$ and different depths $(0-10,10-20$, and $20-30 \mathrm{~cm})$ consequently. The concentrations of heavy metals such as chromium, iron, manganese, nickel, and zinc were sequentially extracted and measured using portable $\mathrm{X}$-ray fluorescence at the soil and water department laboratories. The heavy metals concentration of the soil samples was significantly affected by both factors (distances and depths). Fe had the highest concentration value as ranged from 486.0 to $520.2 \mathrm{mg} / \mathrm{kg}$ with a mean $(502.9 \mathrm{mg} / \mathrm{kg}$ ), while $\mathrm{Cr}$ and $\mathrm{Zn}$ had the lowest concentration value, $\mathrm{Cr}$ ranged from 0.0 to $9.33 \mathrm{mg} / \mathrm{kg}$ with a mean $(3.22 \mathrm{mg} / \mathrm{kg})$ and $\mathrm{Zn}$ ranged from 0.0 to $1.9 \mathrm{mg} / \mathrm{kg}$ with a mean $(1.43 \mathrm{mg} / \mathrm{kg})$. Mn concentration ranged from 9.6 to $13 \mathrm{mg} / \mathrm{kg}$ with a mean $(11.55 \mathrm{mg} / \mathrm{kg})$ and Ni concentration ranged from 4.3 to $10.03 \mathrm{mg} / \mathrm{kg}$ with a mean $(7.40 \mathrm{mg} / \mathrm{kg})$. The geoaccumulation index values of most samples located under the class (1) uncontaminated to moderate index.

Keywords: Heavy metals; Oil refinery; Soil pollution and Geoaccumulation index

\section{INTRODUCTION}

Oil is a complex mixture of aliphatic, alicyclic, aromatic hydrocarbons, and non-hydrocarbon compounds, including heavy metals, as well as varying amounts of oxygen (Okoye and Okwute, 2014). Petroleum pollutions can affect soil physical and chemical characteristics. Oil is usually caused by an anaerobic environment in the soil through the inoculation of soil particles and preventing the spread of air in soil pores and affecting microbial communities in the soil (Ying et al., 2013).

$\mathrm{X}$-ray fluorescence (XRF) is one of the preferred methods for assessing the elemental composition of soils and sediments as it is a rapid and inexpensive method. Quantitative and qualitative analyses by XRF can be determined simultaneously in a short time without demanding chemicals for digestion and many elements (Ene et al., 2009). The main aim of this research is to determine the relationships between soil physicochemical properties of the nearby oil refinery factory with their contaminations of heavy metal in soils in a Kasnazan in Erbil City/Kurdistan region. In addition, to understand the effects of different distances and depths of the distribution of heavy metals in the soil samples. Finally, studying the geoaccumulation index $\left(\mathrm{I}_{\mathrm{ged}}\right)$ values as an indicator of soil contamination.

\section{MATERIALS AND METHODS}

Eighteen soil samples from six points in both directions $(\mathrm{E}$ and $\mathrm{W}$ ) [Figures $1 \mathrm{a}$ and $\mathrm{b}$ ] with a different distance $(0.5,1$, and $1.5 \mathrm{~m})$ from source with three various depths $(0-10,10-20$, and $20-30 \mathrm{~cm})$ collected from surrounding oil refinery factory on April 01, 2018, to evaluate effects of oily wastes from the refinery on soil pollution.

The physical and chemical analyses of the soil samples were done in soil and water department laboratories as shown in Table 1. These analyses performed as follows: Particle size distribution, using the hydrometer method according to (Klute, 1986). The $\mathrm{pH}$ of soil extract was measured by microprocessor $\mathrm{pH}$ meter depending on Jackson's procedure (1958).

Organic matter was determined by the modified (Walkley and Black) method as described by Jackson (1958). Total calcium carbonate $\left(\mathrm{CaCO}_{3}\right)(\mathrm{g} / \mathrm{kg})$ which involves the 
Table 1: Some chemical, physical properties, and the mean of heavy metals concentrations of the studied soil

\begin{tabular}{|c|c|c|c|c|c|c|c|c|c|c|c|c|c|c|}
\hline \multirow{2}{*}{$\begin{array}{l}\text { Sample } \\
\text { direction }\end{array}$} & \multirow{2}{*}{$\begin{array}{l}\text { Loc. } \\
\text { No. }\end{array}$} & \multirow{2}{*}{$\begin{array}{l}\text { Distance from } \\
\text { the source of } \\
\text { pollution }(\mathrm{m})\end{array}$} & \multicolumn{4}{|c|}{ Particle size distribution \% } & \multirow{2}{*}{$\mathrm{pH}$} & \multirow{2}{*}{$\frac{\mathrm{T} . \mathrm{CaCO}_{3}}{\mathrm{~g} / \mathrm{k}}$} & \multirow{2}{*}{ OM } & $\mathrm{Zn}$ & \multirow[t]{2}{*}{$\mathrm{Fe}$} & \multirow{2}{*}{$\frac{\mathrm{Mn}}{\mathrm{mg} / \mathrm{kg}}$} & \multirow[t]{2}{*}{$\mathrm{Ni}$} & \multirow[t]{2}{*}{$\mathrm{Cr}$} \\
\hline & & & Sand & Silt & Clay & $\begin{array}{c}\text { Textural } \\
\text { name }\end{array}$ & & & & & & & & \\
\hline \multirow[t]{4}{*}{$E$} & 1 & 0.5 & 27 & 29 & 44 & \multirow[t]{4}{*}{ Clay } & 7.15 & 391.7 & 14.29 & 1.80 & 513.6 & 12.00 & 8.60 & 5.00 \\
\hline & 2 & 1.0 & 29 & 29 & 42 & & 7.30 & 380.0 & 26.61 & 1.90 & 509.0 & 13.00 & 10.0 & 5.00 \\
\hline & 3 & 1.5 & 33 & 26 & 41 & & 7.01 & 313.3 & 23.75 & 1.73 & 520.2 & 9.67 & 5.70 & 0.00 \\
\hline & & & & & & & & & & 2.21 & 42.28 & 5.33 & 6.40 & 10.2 \\
\hline \multirow[t]{3}{*}{ W } & 4 & 0.5 & 33 & 26 & 41 & Clay & 7.09 & 408.3 & 10.00 & 1.90 & 486.0 & 12.33 & 8.60 & 9.33 \\
\hline & 5 & 1.0 & 35 & 25 & 40 & \multirow{3}{*}{$\begin{array}{l}\text { Clay } \\
\text { loam }\end{array}$} & 7.27 & 443.3 & 7.05 & 1.27 & 487.2 & 11.67 & 7.17 & 0.00 \\
\hline & 6 & 1.5 & 35 & 25 & 40 & & 7.14 & 420.0 & 8.75 & 0.00 & 501.4 & 10.67 & 4.30 & 0.00 \\
\hline LSD 0.05 & & & & & & & & & & 1.27 & 25.57 & 4.61 & 7.58 & 9.32 \\
\hline
\end{tabular}

LSD: Least significant difference

dissolution of carbonate in excess of $\mathrm{HCl}(1 \mathrm{~N})$ followed by back titration with $(1 \mathrm{~N}) \mathrm{NaOH}$ as described in Rowell (1996). Total heavy metal concentrations in soil samples $(\mathrm{mg} / \mathrm{kg})$ directly analyzed by the XRF method after drying, sieving by $2 \mathrm{~mm}$, and powdering of the material. Heavy metals were measured by Portable (X-MET7500) XRF Analyzer (XRF) (Sitko et al., 2004). For the evaluation of soil contamination by heavy metals, $\mathrm{I}_{\text {geo }}$ was calculated using the below equation (Kabata-Pendias and Pendias, 2001 and Ahiamadjie et al., 2011).

$$
I_{g e o}=\log _{2} \frac{c n}{B n 1.5}
$$

Where:

$\mathrm{Cn}$ represents the measured concentration $(\mathrm{mg} / \mathrm{kg})$ of the element of interest $n$.

$B n$ is the background concentration of element $n(\mathrm{mg} / \mathrm{kg})$ an abundance of chemical elements in the continental crust or is the concentration of the metal in the unpolluted sample or control.

1.5: The background matrix correction factor due to lithogenic effects.

\section{RESULTS AND DISCUSSION}

\section{The Effect of Distance from the Source of Pollution on Heavy Metals Concentration $(\mathrm{mg} / \mathrm{kg}$ ) in Soils}

The mean concentrations of heavy metals were varying per the location of the sample. Table 1 shows the mean concentrations of $\mathrm{Fe}, \mathrm{Mn}, \mathrm{Zn}, \mathrm{Ni}$, and $\mathrm{Cr}$ were 502.9, 11.55, $1.43,7.41$, and $3.22 \mathrm{mg} / \mathrm{kg}$, respectively. Iron showed the highest concentration value while chromium showed the lowest concentration value.

\section{Iron $(\mathrm{Fe})$}

The highest value of Fe concentration $(520.2 \mathrm{mg} / \mathrm{kg}$ ) was recorded from the location, number (3) in the E direction which lie $(1.5 \mathrm{~m})$ away from the pollution source while the lowest value of iron $(486.0 \mathrm{mg} / \mathrm{kg})$ was obtained from the location, number (4) in the $\mathrm{W}$ direction which lie $(0.5 \mathrm{~m})$ away from the source of pollution, this is maybe due to the content of organic matter, $\mathrm{pH}$, or type of parent material due to the relations differ between soil properties.

These results showed that $\mathrm{Fe}$ was increased with increase of distance from the source of pollution (oil leakage), this may be due to Fe has a capacity of migration over a long distance and also may be due to high content of organic matter due to the organic matter increase of heavy metals concentration in the soil whereas organic matter possess high sorption capacity for metals (Khan et al., 2016).

\section{Chrome (Cr), manganese (Mn), nickel (Ni), and zinc $(\mathrm{Zn})$}

Table 1 explained that the highest value of $\mathrm{Cr}$ concentration $(9.33 \mathrm{mg} / \mathrm{kg}$ ) was recorded from a location number (4) in the $\mathrm{W}$ direction which lies $(0.5 \mathrm{~m})$ away from the source of pollution while the lowest value of $\mathrm{Cr}(0.0 \mathrm{mg} / \mathrm{kg})$ was recorded from the location, number (3) in the E direction which lies $(1.5 \mathrm{~m})$ away from the source of pollution and location number (5 and 6 ) in the $\mathrm{W}$ direction which lies $(1$ and $1.5 \mathrm{~m}$ ) away from the source of pollution.

The highest value of $\mathrm{Mn}$ concentration (13 mg/kg) was recorded from the location, number (2) in the E direction which lies $(1 \mathrm{~m})$ away from the source of pollution while the lowest value of $\mathrm{Mn}(9.67 \mathrm{mg} / \mathrm{kg})$ was obtained from the location number (3) in the E direction which lies $(1.5 \mathrm{~m})$ away from the source of pollution.

The highest value of Ni concentration $(10.03 \mathrm{mg} / \mathrm{kg})$ was recorded from a location number (2) in the E direction which lies $(1 \mathrm{~m})$ away from the source of pollution while the lowest value of $\mathrm{Ni}(4.3 \mathrm{mg} / \mathrm{kg})$ was obtained from a location number $(6)$ in the $\mathrm{W}$ direction which lies $(1.5 \mathrm{~m})$ away from the source of pollution. The highest value of $\mathrm{Zn}$ concentration $(1.9 \mathrm{mg} / \mathrm{kg})$ was recorded from a location number (2) in the E direction which lies $(1 \mathrm{~m})$ away from the source of pollution, while the lowest value of $\mathrm{Zn}(0.0 \mathrm{mg} / \mathrm{kg})$ was obtained from the location (6) in 
the $\mathrm{W}$ direction which lies $(1.5 \mathrm{~m})$ away from the pollution source.

These results in Table 1 showed that the metals of $\mathrm{Cr}, \mathrm{Mn}$, $\mathrm{Ni}$, and $\mathrm{Zn}$ were a higher value when the samples near from the source of pollution (oil leakage) and decreased with increasing the distance from the oil leakage. These high levels of these metals $\mathrm{Cr}, \mathrm{Mn}, \mathrm{Ni}$, and $\mathrm{Zn}$ may be due to these metals recorded from the locations near from the oil leakage which contained a high amount of oil spill and oil spill release a high amount of heavy metals into ecosystems. Basically, heavy metals such as $\mathrm{Ni}$ and $\mathrm{Cr}$ present in crude oil and drilling fluid which widely used in oil field industries. Heavy metals are common portions of crude oil and drilling fluid applied in oil exploration industries (Mustafa et al., 2015).

Table 2 showed some heavy metals concentration in various countries and in different years. The highest value of $\mathrm{Fe}$ that recorded from the study area (oil refinery leakage) of soil samples was lower than the values of Fe in Iran, Malaysia, and Nigeria. The highest value of $\mathrm{Cr}$ was lower than the limits of $\mathrm{Cr}$ in China and Nigeria while higher than the value in Iran and the USA and near with the value of Poland. The highest value of Mn was lower than the maximum limits of Mn in China, Nigeria, Poland, and the USA while higher than the value in Malaysia. The highest value of $\mathrm{Ni}$ was lower than the values of $\mathrm{Ni}$ in China and equal with Iran, Poland, and the USA and higher than the allowable limit of $\mathrm{Ni}$ in Nigeria. The highest value of $\mathrm{Zn}$ was lower than the limit of $\mathrm{Zn}$ in China, Malaysia, Nigeria, and the USA while in the same range with Iran and Poland.

\section{Heavy Metals Concentration $(\mathrm{mg} / \mathrm{kg}$ ) in Different Depths}

The depth of soil sampling affected significantly $(P \leq 0.05)$ on total heavy metals concentrations in all locations [Figure 2]. In general, at the E direction and according to these results above were observed that the heavy metals concentration such as Fe was increased with depth at the first distance $(0.5 \mathrm{~m})$ away from the source of pollution while $\mathrm{Mn}, \mathrm{Ni}, \mathrm{Zn}$, and $\mathrm{Cr}$ were decreased with depth.

The increases of Fe with depth and the lowest values of it at the sublayer may be due to this distance $(0.5 \mathrm{~m})$ lies near from the source of pollution, which have high contents of carbon dioxide and the accumulation of carbon dioxide causes reduction of iron in the soil (Lovley, 1991), another reason is the high amount of $\mathrm{CaCO}_{3}$ in this site which causes decrease availability of Fe (Ochecova et al., 2014).

The decrease of $\mathrm{Mn}, \mathrm{Ni}, \mathrm{Zn}$, and $\mathrm{Cr}$ with the depth may be due to an increase of $\mathrm{Fe}$ with the depth; due to $\mathrm{Fe}$ has a negative correlation with $\mathrm{Mn}, \mathrm{Ni}, \mathrm{Zn}$, and $\mathrm{Cr}$ (Adeyi and Torto, 2014). As well as another reason a decrease of $\mathrm{Zn}$ is may be due to the accumulation of a high amount of calcium which causes decrease levels of $\mathrm{Zn}$ in the soil (Henriques et al., 2012).

In the third distance $(1.5 \mathrm{~m})$ away from the source of pollution also $\mathrm{Fe}$ was decreased with depth while $\mathrm{Mn}, \mathrm{Ni}$, $\mathrm{Zn}$, and $\mathrm{Cr}$ were increased with depth and these results are opposite with first distance $(0.5 \mathrm{~m})$, and this means that the distance was affected on the depth of heavy metals

Table 2: Some result values of heavy metal in soils were given in various countries and in different years $(\mathrm{mg} / \mathrm{kg})$

\begin{tabular}{|c|c|c|c|c|c|}
\hline Elements & $\mathrm{Cr}$ & $\mathrm{Fe}$ & $\mathrm{Mn}$ & $\mathrm{Ni}$ & $\mathrm{Zn}$ \\
\hline China $^{1}$ & $19-150$ & ---- & 134 & 77 & 1.9 \\
\hline USA $^{1}$ & 6.58 & ---- & 43 & 2.44 & 12.6 \\
\hline Poland ${ }^{1}$ & $3.7-75$ & --- & 83 & $3-27$ & 10.5 \\
\hline Nigeria $^{2}$ & 18.7 & 9180 & 40 & 5.77 & 45.9 \\
\hline $\operatorname{Iran}^{3}$ & 6 & 24100 & ---- & $10-20$ & $10-50$ \\
\hline Malaysia ${ }^{4}$ & ---- & 44500 & 3.99 & ---- & 54.3 \\
\hline Iraq $(\text { Erbil })^{5}$ & --- & $187.3-1073$ & ---- & $7.74-39.41$ & --- \\
\hline Iraq (Erbil) ${ }^{6}$ & $45.3-88.9$ & ---- & ---- & $20.8-103.12$ & $43.10-84.5$ \\
\hline Present study & 9.33 & 520.2 & 13 & 10.03 & 1.9 \\
\hline Permissible limits ${ }^{7}$ & $5-120$ & $5000-50000$ & $350-2000$ & $5-500$ & $80-120$ \\
\hline
\end{tabular}

${ }^{1}$ (Yahaya et al., 2009), ${ }^{2}$ (Adeyi and Torto, 2014), ${ }^{3}$ (Kakhki et al., 2013), ${ }^{4}$ (Sakawi et al., 2013), ${ }^{5}$ (Ahmed, 2012), ${ }^{6}$ (Sadeq, 2015), (Kabata-Pendias and Pendias, 2001) ${ }^{7}$

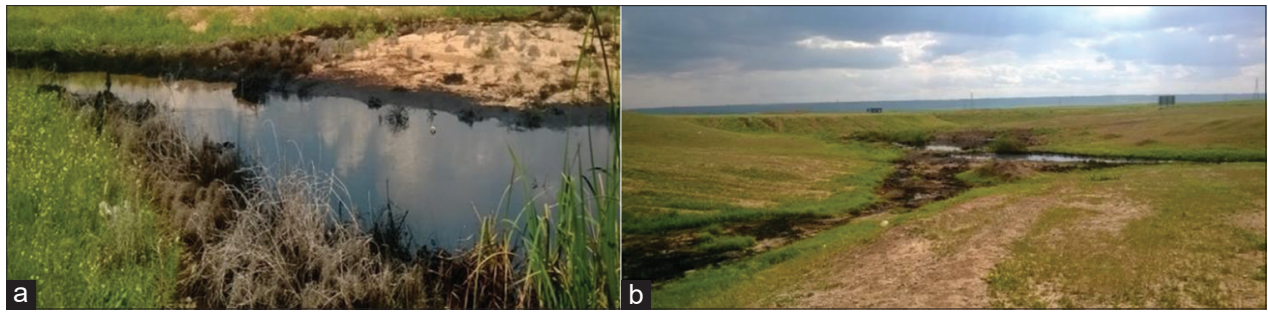

Figure 1: (a and b) The leachate samples were collected on the ground 

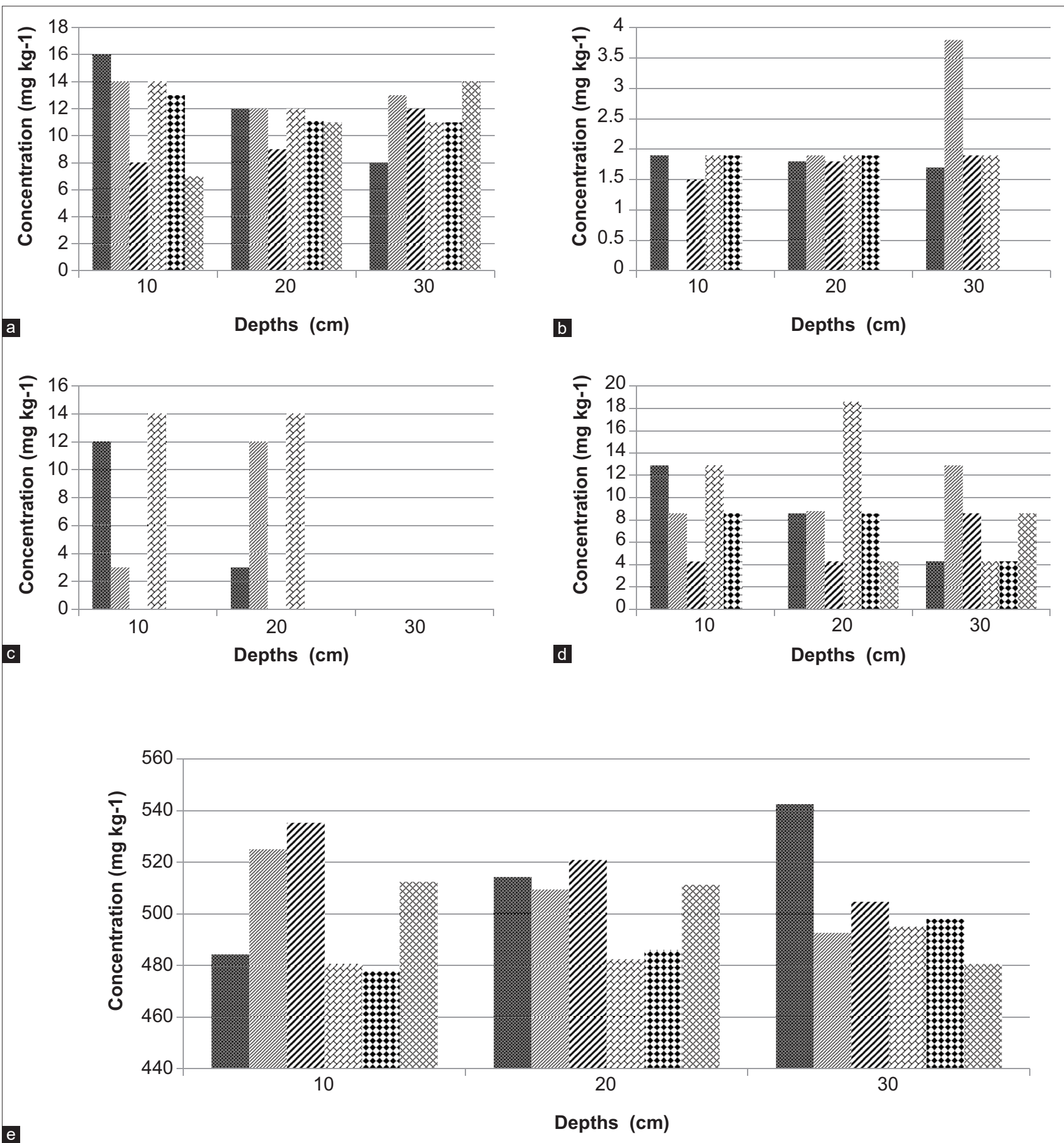

Figure 2: (a-e) Available concentrations (mg/kg) of $\mathrm{Mn}, \mathrm{Zn}, \mathrm{Cr}, \mathrm{Ni}$, and $\mathrm{Fe}$ in different depths 0-10, 10-20, and 20-30 cm with East direction and West direction in $0.5,1$, and $1.5 \mathrm{~m}$ distances

concentration. As well as some heavy metals concentration decreased and others were increased with the increase in distance from the source of pollution (Oladeji et al., 2016).

In the $\mathrm{W}$ direction and through these results above was observed that heavy metals concentration $\mathrm{Fe}$ was increased with depth at the first distance $(0.5 \mathrm{~m})$ away from the source of pollution, while $\mathrm{Mn}, \mathrm{Ni}, \mathrm{Zn}$, and $\mathrm{Cr}$ were decreased with depth. These results were the same as the results of $\mathrm{E}$ direction and have the same reasons been mentioned above.

In the third distance $(1.5 \mathrm{~m})$ away from the source of pollution Fe was decreased with depth while $\mathrm{Mn}$ and $\mathrm{Ni}$ were increased with depth this may be due to the negative correlation between $\mathrm{Fe}$ with $\mathrm{Mn}$ and $\mathrm{Ni}$ because the 
Table 3: Pearson's correlation between heavy metals concentrations and some of the soil chemical properties

\begin{tabular}{|c|c|c|c|c|c|c|c|c|}
\hline & $\mathrm{Fe}$ & Mn & $\mathrm{Zn}$ & $\mathrm{Ni}$ & $\mathrm{Cr}$ & $\mathrm{pH}$ & $\mathrm{T} . \mathrm{CaCO}_{3}$ & OM \\
\hline $\mathrm{Fe}$ & 1.00 & -0.39 & -0.17 & -0.08 & -0.70 & -0.31 & -0.82 & 0.75 \\
\hline $\mathrm{Mn}$ & & 1.00 & 0.42 & 0.88 & 0.72 & -0.69 & -0.46 & 0.01 \\
\hline $\mathrm{Zn}$ & & & 1.00 & 0.80 & 0.59 & -0.01 & -0.42 & 0.52 \\
\hline $\mathrm{Ni}$ & & & & 1.00 & 0.74 & -0.49 & -0.04 & 0.35 \\
\hline $\mathrm{Cr}$ & & & & & 1.00 & 0.00 & -0.09 & 0.04 \\
\hline $\mathrm{pH}$ & & & & & & 1.00 & 0.58 & -0.02 \\
\hline T.CaCO & & & & & & & 1.00 & -0.81 \\
\hline OM & & & & & & & & 1.00 \\
\hline
\end{tabular}

OM: Organic matter

increase in Fe caused decrease of $\mathrm{Mn}$ and $\mathrm{Zn}$ value in the soil (Adeyi and Torto, 2014).

Whereas the value of $\mathrm{Zn}$ and $\mathrm{Cr}$ in this distance $(1.5 \mathrm{~m})$ away from the source of pollution was $(0.0 \mathrm{mg} / \mathrm{kg})$, and this may be due to this distance was away from the source of pollution (oil refinery leakage) and this cause decrease amount of $\mathrm{Cr}$ and $\mathrm{Zn}$ because oil causes increase concentration of these metals in the soil and when oil decrease, the amount of $\mathrm{Cr}$ and $\mathrm{Zn}$ decreases (Adesina and Adelasoye, 2014). At the same time, another reason for the decreased value of $\mathrm{Zn}$ in this distance was may be due to this distance contains a high value of phosphorus and high levels of phosphorus may decrease the availability of zinc (Mousavi et al., 2012).

\section{The Interactions between Heavy Metal and Soil Chemical Properties}

Table 3 shows the Pearson's correlation analysis performed between metals (Fe, Mn, Cr, Ni, and $\mathrm{Zn}$ ) were closely associated with each other. The negative correlation of $\mathrm{Fe}$ with $\mathrm{Mn}, \mathrm{Zn}, \mathrm{Ni}$, and $\mathrm{Cr}$ which $\mathrm{r}=-0.39,-0.17,-0.08$, and -0.27 , as shown in Table 4 , this means there were antagonistic relations between them. Iron can induce nickel deficiency so there was a negative correlation between $\mathrm{Fe}$ and $\mathrm{Ni}$ (Adeyi and Torto, 2014). Manganese has a positive correlation with $\mathrm{Zn}, \mathrm{Ni}$, and $\mathrm{Cr}$ which $\mathrm{r}=(0.42,0.88$, and $0.72)$; these results mean that $\mathrm{Mn}$ has synergistic relations with Zn, Cr, and Ni (Mudiaga et al., 2011).

Zinc has a positive correlation with $\mathrm{Ni}$ and $\mathrm{Cr}$, which $\mathrm{r}=0.80$ and 0.59 ; these results mean that $\mathrm{Zn}$ has a synergistic relationship with those metals (Ololade, 2014). Nickel has a positive correlation with $\mathrm{Cr}$ which $\mathrm{r}=0.74$; this result means that $\mathrm{Ni}$ has a synergistic relationship with $\mathrm{Cr}$ (Skrbic and Mladenovic, 2010). There is a negative correlation between $\mathrm{pH}, \mathrm{T} . \mathrm{CaCO}$ with heavy metals concentration and a positive correlation between EC and organic matter content with heavy metals in the soil samples.

\section{$I_{\text {geo }}$ Measurements}

The $I_{\text {geo }}$ was used as a quantitative determination of the spatial distribution (random and systematic variation) of
Table 4: Geoaccumulation classes

\begin{tabular}{lcl}
\hline $\begin{array}{l}\text { I }_{\text {geo }} \text { contamination } \\
\text { value }\end{array}$ & $\begin{array}{c}\text { Geo-accumulation } \\
\text { class }\end{array}$ & Index, I Ieo \\
\hline$<0$ & 0 & $\begin{array}{l}\text { Particularly } \\
\text { uncontaminated } \\
\text { Uncontaminated to } \\
\text { moderate }\end{array}$ \\
$0-1$ & 1 & Moderate \\
$1-2$ & 2 & Moderate to strong \\
$2-3$ & 3 & Strong \\
$3-4$ & 4 & Strong to very strong \\
$4-5$ & 5 & Very strong \\
\hline$>5$ & 6 & \\
\hline
\end{tabular}

$\mathrm{I}_{\text {geo: }}:$ Geoaccumulation index

Table 5: Graphical representations of the geoaccumulation index of metals in the soils around oil refinery factory

\begin{tabular}{|c|c|c|c|c|c|c|c|}
\hline \multirow[t]{2}{*}{ Directions } & \multirow{2}{*}{$\begin{array}{l}\text { Locations } \\
\text { No. }\end{array}$} & \multirow{2}{*}{$\begin{array}{l}\text { Distances } \\
(\mathrm{m})\end{array}$} & $\mathrm{Cr}$ & $\mathrm{Fe}$ & $\mathrm{Mn}$ & $\mathrm{Ni}$ & $\mathrm{Zn}$ \\
\hline & & & \multicolumn{5}{|c|}{ Geoaccumulation index } \\
\hline \multirow[t]{3}{*}{$E$} & 1 & 0.5 & 0.30 & 0.21 & 0.25 & 0.25 & 0.29 \\
\hline & 2 & 1.0 & 0.30 & 0.21 & 0.27 & 0.30 & 0.30 \\
\hline & 3 & 1.5 & 0.00 & 0.21 & 0.20 & 0.17 & 0.27 \\
\hline \multirow[t]{3}{*}{ W } & 4 & 0.5 & 0.56 & 0.20 & 0.26 & 0.25 & 0.30 \\
\hline & 5 & 1.0 & 0.00 & 0.20 & 0.24 & 0.21 & 0.20 \\
\hline & 6 & 1.5 & 0.00 & 0.21 & 0.22 & 0.13 & 0.00 \\
\hline Average & & & 0.19 & 0.21 & 0.24 & 0.22 & 0.23 \\
\hline
\end{tabular}

heavy metals in surface soil horizons in the study area. A good indicator of environmental pollution of soils by heavy metals is their $I_{\text {geo }}$ (Grzebisz et al., 2002).

Sapana et al. (2014) showed that the index of geoaccumulation consists of seven grades, as shown in Table 4.

The results in Table 5 showed that most of the samples were located under the class (1) and the index of $\left(\mathrm{I}_{\text {geo }}\right)$ value was in the uncontaminated to moderate.

The highest value of Ni may be due to nickel release from industrial sources due to its being a trace contaminant in fossil fuels, also a high amount of nickel emitted from the dust of refinery and industries (Karbassi et al., 2015). The lowest value of Fe may be due to the presence of the high amount of $\mathrm{CaCO}_{3}$ and $\mathrm{pH}$, which causes decrease levels of Fe availability. As well as, the low value of Fe 
may be due to the high concentration of zinc because excess in $\mathrm{Zn}$ causes decreases concentration of iron (Chilian et al., 2015).

\section{CONCLUSION}

The outcomes of this research revealed that the pollution level of the various locations within the study area was placed under uncontaminated to moderate contaminate classes; this might be due to the refinery plants which recently built in this area. Furthermore, the heavy material concentrations in the affected area were higher compared to uncontaminated places.

To reduce the impacts of this issue, the refinery oil factories have to build within sufficient distances from urban areas. Moreover, conducting extensive studies on the impacts of oil refinery factories on the environment and increasing public awareness about this serious environmental issue through education and publishing brochures in neighborhood areas are ways to improve this issue.

\section{REFERENCES}

Adesina, G. O. and K. A. Adelasoye. 2014. Effect of crude oil pollution on heavy metal contents, microbial population in soil, and maize and cowpea growth. J. Agric. Sci. 5: 43-50.

Adeyi, A. A. and N. Torto. 2014. Profiling heavy metal distribution and contamination in soil of old power generation station in Lagos, Nigeria. Am. J. Sci. Tech. 1(1): 1-10.

Ahiamadjie, H. O., K. Adukpo, J. B. Tandoh, O. Gyampo, M. Nyraku, I. I. Mumuni, O. Agyemang, M. Ackah, F. Otoo and S. B. Dapare. 2011. Determination of the element content in soil around diamond cement factory, Aflao. J. Environ. Res. Earth Sci. 3(1): 46-50.

Ahmed, I. T. 2012. Application of Chemical and Spectral Analysis Techniques for Assessing Soil Pollution by Some Heavy Metals in Selected Sites of Arbil City, Iraqi Kurdistan Region. Ph.D. Thesis, Biological Science Colleges and University, Salahaddin. p108.

Chilian, A., R. O. Bancuta, I. Bancuta, R. Setnescu, R. M. Ion, C. Radulescu, T. Setnescu, C. Stihi, A. I. Gheboianu and E. D. Chelarescu. 2015. Study of the influence of $\mathrm{Zn}$ concentration on the absorption and transport of Fe in Maize by AAS and EDXRF analysis techniques. J. Environ. Phys. 67(3): 1138-1151.

Ene, A., C. Stihi, I. V. Popescu, A. Gheboianu, A. Bosneaga and I. Bancuta. 2009. Comparative studies on heavy metal content of soils using AAS and EDXRF atomic spectrometric techniques. J. Ann. Univ. Galati Fasc. 32(2): 42-51.

Grzebisz, W., L. Cieśla, J. Komisarek and J. Potarzycki. 2002. Geochemical assessment of heavy metals pollution of urban soils. Pol. J. Environ. Stud. 11(5): 493-499.

Henriques, A. R., A. C. Junior and M. Aarts. 2012. Strategies to increase zinc deficiency tolerance and homeostasis in plants. J. Brazil. Soc. Plant. Physiol. 24(1): 3-8.
Jackson, M. L. 1958. Soil Chemical Analysis. Prentice Hall Inc., USA. p521.

Kabata-Pendias, A. and H. Pendias. 2001. Trace Elements in Soils and Plants. $3^{\text {rd }}$ ed. CRC Press, Boca Raton, USA. p403.

Kakhki, F. V., M. P. Zakaria, M. Mohammadi and E. V. kakhki. 2013. Assessment of heavy metals contamination in topsoil of northern coasts of Persian Gulf. J. Environ. Stud. 1(1): 1-12.

Karbassi, A. R., S. Tajziehchi and S. Afshar. 2015. An investigation on heavy metals in soils around oil field area. J. Environ. Sci. Manage. 1(4): 275-282.

Khan, N., Z. Shah, M. Adnan, M. Ali, B. Khan, I. A. Mian, A. Ali, M. Zahoor, M. Roman, L. Ullah, A. Khaliq, W. A. Khan and A. Alam. 2016. Evaluation of soil for important properties and chromium concentration in the basin of chromite hills in lower Malakand. J. Adv. Environ. Biol. 10(7): 141-147.

Klute, A. 1986. Methods of Soil Analysis American Society of Agronomy Inc., Madison. Wisconsin. p441.

Lovley, D. R. 1991. Dissimilatory Fe and Mn reduction. J. Microbiol. Rev. 55(2): 259-287.

Mousavi, S. R., M. Galavi and M. Rezaei. 2012. The interaction of zinc with other elements in plants: A review. J. Agric. Crop Sci. 4(24): 1881-1884.

Mudiaga, O. C., O. C. Nicolas and O. C. Leo. 2011. Trace metals geochemistry of crude oils from Umutu/Bomu fields in South West Niger delta Nigeria. J. Eng. Environ. Res. 1(1): 139-146.

Mustafa, A. D., Juahir, H., Yunus, K., Amran, M. A., Hasnam, C. N. C., Azaman, F., Abidin, I. Z., Azmee, S. H. and N. H. Sulaiman. 2015. Oil spill related heavy metal a review. Malays. J. Anal. Sci. 19(6): 1348-1360.

Ochecova, P., P. Tlustos and J. Szakova. 2014. Wheat and soil response to wood fly ash applicationin contaminated soils. J. Agron. Soil. Environ. Qual. 106(3): 995-1002.

Okoye, C. O. and G. A. Okwute. 2014. Heavy metal concentrations in food crops grown in crude oil impacted soils in Olomoro, delta state-Nigeria and their health implications. J. Eng. Sci. Invent. 3(3): 15-21.

Oladeji, J. T., S. O. Adetola and A. D. Ogunsola. 2016. Heavy metals concentration in soil of Ogbomoso and its environs. J. Environ. Sci. Toxicol. 4(1): 1-5.

Ololade, I. A. 2014. An assessment of heavy-metal contamination in soils with in auto-mechanic workshops using enrichment and contamination factors with geoaccumulation indexes. J. Environ. Protec. 5: 970-982.

Rowell, D. L. 1996. Soil Science: Methods and Application. Longman Publishing, Harlow, UK. p86.

Sadeq, S. J. A. 2015. Assessment the Impact of Soils Texture, Compost Types and Compost Levels on Heavy Metals Content, Enzymatic Activity and Wheat Yield. M.Sc. Thesis, Science College, University of Salahaddin. p146.

Sakawi, Z., M. R. Ariffin, S. A. Mastura and M. F. M. Jali. 2013. The analysis of heavy metal concentration per distance and depth around the vicinity of open landfill. J. Appl. Sci. Eng. Technol. 5(24): 5619-5625.

Sapana, G., J. Vinod, M. Natalija, K. Veronika and J. S. Solanki. 2014. Assessment of geoaccumulation index of heavy metals and source of contaminationby multivariate factors analysis. Int. J. Hazard. Mater. 2(2): 18-22.

Sitko, R., B. Zawisza, J. Jurczyk, F. Buhl and U. Zielonka. 2004. Determination of high $\mathrm{Zn}$ and $\mathrm{Pb}$ concentrations in polluted soils using energy-dispersive X-ray fluorescence spectrometry. J. Environ. Stud. 13(1): 91-96.

Skrbic, B. and N. D. Mladenovi. 2010. Chemometric interpretation of heavy 
metal patterns in soils worldwide. J. Chemosphere. 8: 1360-1369.

Yahaya, M. I., S. Mohammad and B. K. Abdullahi. 2009. Seasonal variations of heavy metals concentration in abattoir dumping site soil in Nigeria. J. Appl. Sci. Environ. Manage. 13(4): 9-13.
Ying, W., F. Jiang, L. Qianxin, L. Xianguo, W. Xiaoyu and W. Guoping. 2013. Effects of crude oil contamination on soil physical and chemical properties in Momoge Wetland of China. J. Chin. Geogra. Sci. 23(6): 708-715. 